\begin{tabular}{c|l|l|l|l}
\hline Volume 1 & Issue 1 & February (2021) & DOI: $10.47540 /$ ijias.v1i1.159 & Page: $40-43$ \\
\hline
\end{tabular}

\title{
Education on the Fulfillment of Balanced Nutrition and My Plate Contents for Students of SMPN 7 Kendari
}

\author{
Lisnawaty $^{1}$, Rizki Eka Sakti Octaviani ${ }^{2}$, Yusuf Sabilu ${ }^{3}$ \\ ${ }^{1,2,3}$ Nutrition Study Program, Halu Oleo University, Indonesia \\ Corresponding Author: Lisnawaty; Email: lisnawaty@uho.ac.id
}

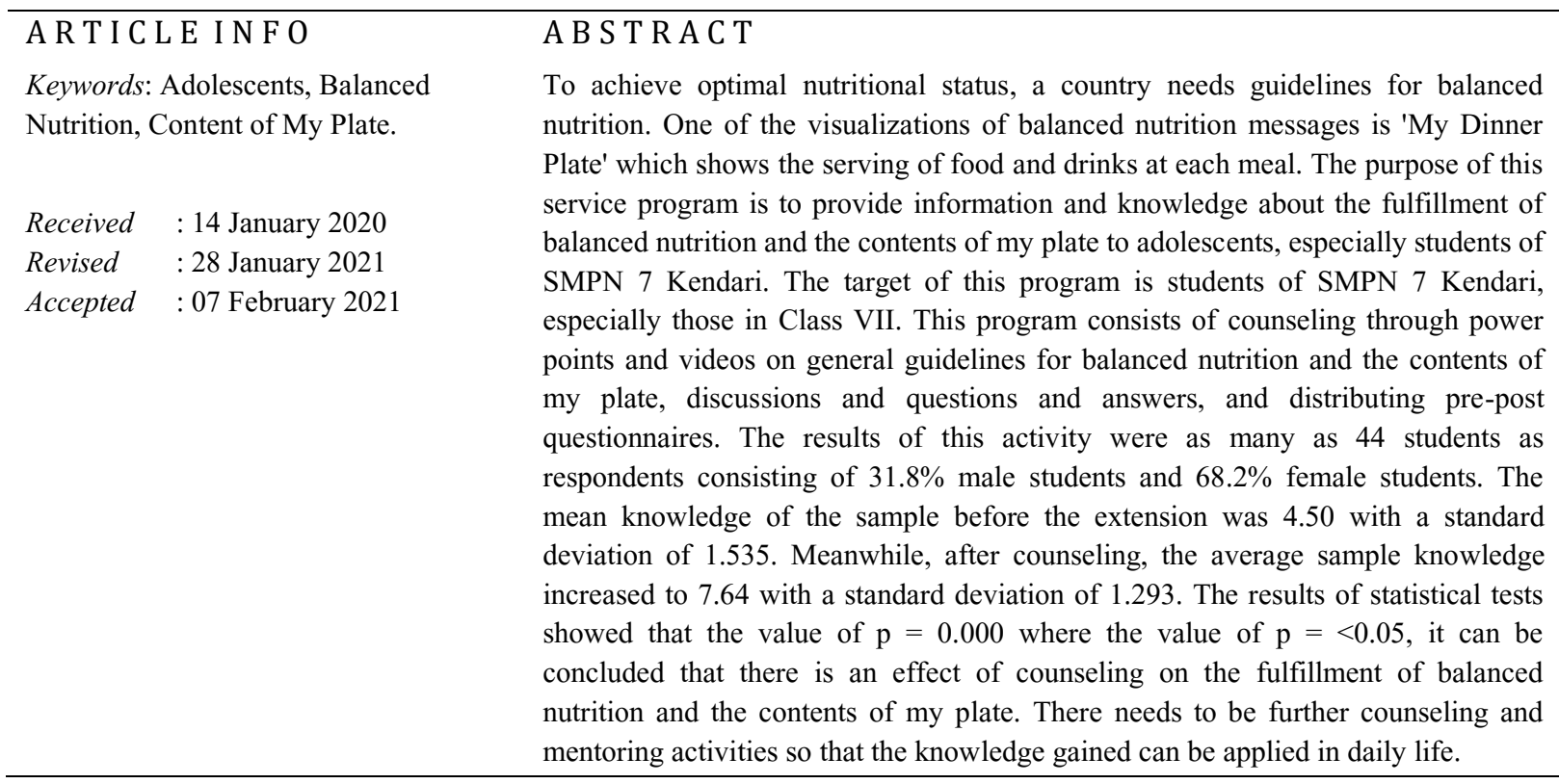

\section{INTRODUCTION}

Adolescence is a transitional age from childhood to adulthood characterized by rapid physical growth and psychological development (Mary, 2002). The adolescent age category starts from 10 years to 21 years (Adiningsih, 2002). Problems related to food consumption are the very diverse habits of adolescents towards the food they consume, such as indifference, to the choice of food they consume even though it is not by nutritional needs, overeating, following the trend with fast food without paying attention to the adequacy of the nutrition they need, forgetting time to eat because of dense activities and so on (Moehji, 2003).

To achieve optimal nutritional status, a country needs guidelines for balanced nutrition. It is not only enough to be printed, but the guidelines for balanced nutrition need to be socialized so that they can become guidelines for eating people in a balanced diet. One of the visualizations of balanced nutrition messages is 'My Dinner Plate' which shows the serving of food and drinks at every meal (Notoatmodjo, 2007). According to the general guidelines for balanced nutrition (PUGS) the composition of dishes must consist of rice, side dishes, vegetables, and fruits which are naturally very high in value, namely staple foods as a source of energy, side dishes as a source of protein and fat, vegetables and fruit as a source of minerals and vitamins. The practice of balanced nutrition is a response to knowledge and attitudes towards balanced nutrition which includes consuming a balanced diet and having a healthy lifestyle (Supariasa, 2012). 
The contents of my plate describe HEALTHY and BALANCED food, starting from 4 healthy 5 perfect which cannot be sufficient so that it is complemented or transformed by balanced nutrition guidelines with 10 basic messages. The current guidelines for balanced nutrition are focused on four things, namely various kinds of food, drinking at least 8 glasses of water a day, physical activity as well as weighing height and weight, and equipped with Handwashing with Soap (CTPS). The contents of my plate refer to one plate divided into two, 50 percent fruit and vegetable plate, the other 50 percent consists of $1 / 3$ side dish and $2 / 3$ carbohydrates.

Many factors influence the practice of balanced nutrition, including gender, age, and socioeconomic status, place of residence, family habits, knowledge, and attitudes towards balanced nutrition. From the description above, one of the factors related to nutritional problems is knowledge. Knowledge is the result of "knowing" and this occurs after a person senses a certain object, at the time of sensing to produce that knowledge is strongly influenced by the intensity of perceptual attention to the object and most of the human knowledge is obtained through the eyes and ears (Wawan \& Dewi, 2012).

One of the factors that influence knowledge is education. Education is an effort to develop personality and abilities inside and outside the school and lasts a lifetime, and from this education, a person will get information. One of the media to convey and get information is counseling. The extension is all means or efforts to display information messages that the communicator wants to convey so that targets can increase their Table 2. The Influence of Extension on Student Knowledge

\begin{tabular}{|c|c|c|c|c|c|c|c|}
\hline Variable & $\mathrm{N}$ & Mean & SD & SE & Limit Upper & Limit Lower & P-Value \\
\cline { 1 - 5 } After & \multirow{2}{*}{44} & 4,50 & 1,535 & 0,327 & \multirow{2}{*}{$-3,753$} & $-2,520$ & 0,000 \\
\cline { 1 - 3 } Before & & 7,64 & 1,293 & 02,76 & & & \\
\hline
\end{tabular}

Table 2 shows that the mean knowledge of the sample before an extension was 4.50 with a standard deviation of 1.535. Meanwhile, after counseling, the average sample knowledge increased to 7.64 with a standard deviation of 1.293. knowledge, which in turn is expected to change their behavior towards health positively (Notoatmodjo, 2007).

\section{METHODS OF IMPLEMENTATION}

The activities carried out in the community service are:

1. Extension with the lecture method, namely the delivery of material orally by face-to-face with the audience, the material presented is general guidelines for balanced nutrition and the contents of my plate.

2. Discussion and question and answer. The Extension Team opens discussions or questions and answers with extension participants to provide responses and questions that are relevant to the extension material.

3. Documentation, namely the extension team showing some documentation regarding general guidelines for balanced nutrition and the contents of my plate.

4. Evaluation, namely by looking at the average change in knowledge based on the answers to the pre-post counseling questionnaire and using the paired T-test to see whether or not there is an effect on changes in knowledge.

\section{RESULTS AND DISCUSSION}

Table 1. Distribution of Respondents by Gender

\begin{tabular}{|c|c|c|c|}
\hline No & Gender & Total & Percents \\
\hline 1. & Boys & 14 & $31,8 \%$ \\
\hline 2. & Girls & 30 & $68,2 \%$ \\
\hline \multicolumn{2}{|c|}{ Total } & 44 & $100 \%$ \\
\hline
\end{tabular}

Based on Table 1, it is known that the number of students who became respondents was female $(68.2 \%)$.

The results of statistical tests showed that the value of $p=0.000$ where the value of $p=<0.05$, it can be concluded that there is an effect of counseling on the fulfillment of balanced nutrition and the contents of my plate. 
This is in line with the theory of knowledge is a domain of things that can shape behavior. Knowledge is the result of knowing and occurs after people sense a certain object, most of the knowledge is obtained through the eyes and ears (Notoatmodjo, 2007).

Participants' knowledge increases after receiving nutritional counseling so that nutrition counseling can change the eating behavior of adolescents to better according to the 10 general guidelines for balanced nutrition in which there is a concept of recommended food composition to ensure a balance of nutritional substances so that they can supplement nutritional substances which it contains.

Based on the results of this activity, it turned out that many respondents had a poor level of knowledge about Balanced Nutrition General Knowledge. This is due to the lack of education and education on Balanced Nutrition General Knowledge. Without knowledge, a person does not have a basis for making decisions and determining action on the problem at hand. The knowledge in question is knowledge about balanced nutrition, where this knowledge affects attitudes and behavior in choosing food which in turn will affect the nutritional status of the individual concerned (Chatlin, 2010).

Nutritional knowledge has an important role in shaping a person's eating habits because this will affect a person in choosing the type and amount of food consumed. A person who is based on good nutritional knowledge will pay attention to the nutritional state of each food he consumes. Nutritious food is not expensive and delicious food. However, these nutritious foods are foods that can meet the required nutrients. With the aim that these foods provide the appropriate nutrition needed by the body or often called balanced nutrition (Almatsier, 2011).

In this activity, it was found that balanced nutrition counseling had a significant level of knowledge with a p-value of 0.000 . There is a significant influence in this study because the media used other than slide media also uses video media.
In theory, it is said that video added in verbal messages can increase motivation to receive messages and remember them better because video media offers more interesting and less interesting information by displaying motion, pictures, and sound (Cotento, 2007). The results of this service are in line with the results of previous studies which show that the use of balanced nutrition counseling edutainment for young women for video media is more effective in understanding balanced nutrition for young women. Meanwhile, comic media is not effective in understanding the fulfillment of balanced nutrition as measured by the difference in the magnitude of the pretest N-Gain with the posttest videos and comics (Yuliati, Drajat, \& Tutiek, 2014).

Some literature shows that providing nutrition education with the lecture method can increase the level of knowledge, attitudes, and behavior of elementary school students (Sartika, 2012). Also, balanced nutrition education conducted at elementary schools in Cilincing District is quite effective in increasing understanding of balanced nutrition in elementary school children (Palupi, Martien, \& Prita, 2018). Nutrition education can also use other media. As in previous studies, it shows that there are differences in knowledge before and after health education (Syafrawati, 2019). Besides, there is an increase in understanding and improving behavior after being given counseling (Kasuma, Nila, \& dkk, 2018).

\section{CONCLUSION}

Providing education on the fulfillment of balanced nutrition and the contents of my plate through PowerPoint media and videos can increase students' knowledge. The provision of education that is carried out continuously is expected to increase knowledge and ultimately will influence the attitudes and actions of students to be able to implement life behaviors following the guidelines for balanced nutrition and the contents of my plate. There needs to be further counseling and mentoring activities so that the knowledge gained can be applied in everyday life. 


\section{ACKNOWLEDGMENTS}

The implementation of community service activities cannot be separated from the cooperation and support of various parties. The writer's team's gratitude goes to the principal, teachers, and seventh-grade students of SMPN 7 Kendari as well as the village and the entire community of Anggalomelai Village, Abeli District, Kendari City who have helped make our service activities successful.

\section{REFERENCES}

1. Almatsier, S. (2011). Prinsip Dasar Ilmu Gizi. Jakarta: Pt. Gramedia Pustaka Utama.

2. Chatlin, I. (2010). Gambaran Status Gizi Dan Tingkat Pengetahuan Gizi Seimbang Siswa Sdn 121 Manado. Manado: Fkm Universitas Sam Ratulangi.

3. Cotento, I. (2007). Nutrition Education: Linking Research, Theory, and Practice. Sudbury: Jones and Bartlett Publishers.

4. Kasuma, Nila, \& Dkk. (2018). Penyuluhan Kesehatan Gigi Dan Mulut Pada Siswa Sekolah Dasar Sdn 03 Alai Kota Padang Dalam Rangka Memperingati World Oral Health Day Tahun 2017. Warta Pengabdian Andalas.

5. Moehji. (2003). Ilmu Gizi, Edisi 2. Jakarta: Papar Sinar Sinanti.

6. Notoatmodjo, S. (2007). Kesehatan Masyarakat Ilmu Dan Seni. Jakarta: Rineka Cipta.

7. Palupi, K., Martien, S., \& Prita, D. (2018). Edukasi Gizi Seimbang Pada Anak Sekolah Dasar Di Kecamatan Cilincing Jakarta Utara. Abdimas.

8. Sartika, R. (2012). Penerapan Komunikasi, Informasi, Dan Edukasi Gizi Terhadap Perilaku Sarapan Siswa Sekolah Dasar. National Public Health Journal, 76-82.

9. Supariasa, D. (2012). Pendidikan Dan Konsultasi Gizi. Jakarta: Egc.

10. Syafrawati. (2019). Upaya Menurunkan Dampak Negatif Gadget Melalui Media Promosi Kesehatan Pada Siswa Sdn 01 Sawahan Kota Padang. Jurnal Hilirisasi Ipteks.
11. Wawan, A., \& Dewi, M. (2012). Eori Dan Pengukuran Pengukuran Sikap Dan Perilaku Manusia. Yogyakarta: Nuha Medika.

12. Yuliati, Drajat, P., \& Tutiek, R. (2014). Efektivitas Penggunaan Edutainment Konseling Gizi Terhadap Pemahaman Pemenuhan Gizi Seimbang Pada Remaja Putri. Jurnal Pendidikan Matematika Dan Sains, 160-166. 